\title{
RESENHA
}

\section{O crescimento das Relações Internacionais no Brasil*}

JOELSON VELLOZO JÚNIOR**

O Instituto Brasileiro de Relações Internacionais - IBRI, instituição que há muito se dedica ao campo de estudo das Relações Internacionais, e em cujo rol de publicações figura esta Revista Brasileira de Política Internacional, celebrou o seu cinqüentenário, alcançado em 2004, com a publicação de $O$ crescimento das Relaçôes Internacionais no Brasil.José Flávio Sombra Saraiva e Amado Luiz Cervo organizam a obra que pretende capturar as nuances de uma história, longa e multifacetada, focada essencialmente no Estado e na construção da Política Exterior do Brasil (PEB), mas em cujas linhas mais recentes se escreve também a evolução da disciplina e da pesquisa em Relações Internacionais no país. Essa última, observada segundo o ângulo do "conhecimento e ensino das Relações Internacionais no Brasil", é a que inicia o debate que divide o livro em quatro partes. A segunda se dedica ao tema do "poder nacional e segurança"; a terceira parte centra-se nos "brasileiros e o mundo: fluxos humanos, de idéias e de conhecimento"; e a última parte instiga a reflexão sobre "o Brasil e as estruturas econômicas internacionais".

Ao analisar o construto intelectual da disciplina no Brasil, Paulo Fagundes Vizentini e Antonio Carlos Lessa dividem-se em caminhos distintos, mas complementares. O primeiro observa a evolução da produção intelectual e dos estudos acadêmicos da área no País. Assim, ele perpassa desde o seu surgimento, em meados da década de 1970, até a consolidação do campo, da profissão e do seu universo editorial. Ao notar o início difícil e de pouca produção nacional sobre temas internacionais, Vizentini ajuda-nos a revelar a importância do trabalho do IBRI para o crescimento e fortalecimento da área no Brasil. Hoje, vale registrar, parte fundamental da produção nacional é chancelada pela instituição.

Lessa dedica-se à apresentação da história do ensino da disciplina e a confronta com a atualíssima questão da formação de recursos humanos na área. Desde a criação do primeiro curso de graduação, na Universidade de Brasília, e, ainda, a partir do surgimento de programas de pós-graduação em

\footnotetext{
* SARAIVA, José Flávio Sombra Saraiva \& CERVO, Amado Luiz. O crescimento das Relaçōes Internacionais no Brasil. Brasília: Instituto Brasileiro de Relaçôes Internacionais (IBRI), 2005, 308 p., ISBN 85-88270-15-3.

** Mestrando em Relações Internacionais pela Universidade de Brasília - UnB.
} 
diferentes centros no território nacional, o professor e pesquisador convida o leitor a trilhar o caminho da formação do profissional de Relações Internacionais ao longo das últimas décadas e, com isso, compreender o atual estágio do seu desenvolvimento e as perspectivas que se lhe apresentam.

Poder nacional e segurança são objetos de estudo de José Flávio Sombra Saraiva e de Antonio Jorge Ramalho da Rocha. O foco do primeiro é, em essência, a Política Exterior do Brasil nesses cinqüenta anos. Saraiva apresentanos o argumento de que a PEB foi - e ainda é - parte essencial na "formação da nacionalidade e do republicanismo renovado no Brasil na segunda metade do século XX". Fazendo convergir em sua análise PEB e política interna, nacionalismo econômico e autonomia decisória externa, o autor, com uma visão extremamente crítica, leva-nos até os anos da década de 90 por estrada que visa a "encomendar", ao fim do texto, uma nova agenda de ação para mais cinqüenta anos de PEB.

Tradicionalmente relegada a um segundo plano na literatura nacional sobre Relaçôes Internacionais, a geopolítica ganha ares modernos e recebe um tratamento cuidadoso por parte do professor Antonio Jorge Ramalho da Rocha. Espaço e territorialidade, processos políticos e dinâmicas sociais: são todos eles elementos de uma mesma realidade geopolítica, complexa e inacabada, em que agentes internacionais de toda "estatura" envolvem-se de maneira veloz e conecta, formando redes globais, variadas e superpostas. Figura-se aí o estudo da "geopolítica global" e, sobre estes pilares conceituais, o autor pretende desvendar o lugar do Brasil neste ambiente. E é precisamente por ser multifacetada que sua análise chega à conclusão de que o País ocupa, a depender do ângulo que se adote, diferentes posiçóes relativas no mundo, o que resultará - sempre - "das ações que seus cidadãos e seu governo vierem a implementar no futuro próximo".

A terceira parte do livro abre espaço à discussão do brasileiro, o indivíduo, no quadro das Relaçóes Internacionais do Brasil. Difere, portanto, de uma perspectiva estatal/institucional das interações entre o País e o mundo. Dinair Andrade da Silva dá importante contribuição ao "apresentar um balanço das migrações internacionais do Brasil nos últimos cinqüenta anos”. Observando a historia da mobilidade da população brasileira, revela-nos o papel da emigração, questão mais recente e relevante no contexto atual.

Maria Thereza Negrão de Mello examina o turismo e a indústria cultural no País a partir de uma perspectiva cientificamente rigorosa e analiticamente bem informada. O "produto Brasil" de que se ocupa é apresentado diante da perspectiva mais ampla do turismo - como conceito e como prática - e de sua história recente no mundo e no País. Assim, informa os diferentes leitores: desde leigos no tema até os mais informados, que poderão transformar sua forma de pensar e agir em relação ao "produto Brasil". 
A pesquisadora Isabel Canto trata do tema da cooperação científica internacional segundo uma visão centro-periferia que é particularmente interessante. Distingue as formas tradicionais e neocoloniais de cooperação existentes entre os países desenvolvidos e os não-desenvolvidos. Assim, a primeira forma diz respeito a um modo de assistência à pesquisa, muitas vezes unilateral e passivo. Por outro lado, a forma neocolonialista evoluiu para um efetivo intercâmbio de conhecimento entre os parceiros. Ao desenhar o trajeto da cooperação científica no Brasil, com a ajuda de informações sobre as instituições de apoio à pesquisa e o contexto das relaçóes norte/sul, a autora identifica que a tendência para o futuro é, sim, a coexistência destes dois modelos, e não a incorporação de um em detrimento do outro.

A quarta parte do livro dedica-se aos aspectos econômicos das relações internacionais do Brasil. Dércio Garcia Munhoz passa em revista o fenômeno da internacionalização da economia e a sua repercussão perante o grau de autonomia política do Brasil ao longo da segunda metade do século XX. Ele reflete sobre as iniciativas de resistência brasileira à internacionalização do poder nacional e os momentos em que a fragilidade externa da economia vitimou o desenvolvimento e a capacidade de reagir ativamente às dinâmicas do cenário internacional, inclusive e - mais gravemente - na década de 1990.

Paulo Roberto de Almeida apresenta sua análise sobre as finanças internacionais do Brasil neste meio século a contar de 1954. Em suas palavras, o "ensaio tem a intenção de examinar as grandes tendências e discutir os principais problemas da inserção financeira externa do Brasil”, observando seus elementos estruturais, suas instituições e suas fragilidades. Ao percorrer a história, o diplomata brasileiro define fases bem delineadas em nossa história e estabelece, ao cabo, o "perfil" financeiro do País, segundo as condições que nos são apresentadas hoje. Diante das fragilidades eminentes, suas conclusões são menos pessimistas do que o imaginado, e advoga pela idéia de que "capitalismo se faz em casa" e depende essencialmente de nós mesmos.

A última análise do livro, de Heloísa Machado da Silva, apresenta o quadro histórico-evolutivo da política de comércio exterior brasileira desde 1954. A perspectiva da autora, fortemente lastreada por exemplos captados em períodos específicos das décadas do nacional-desenvolvimentismo até momentos recentes de abandono deste curso de ação e de promoção da estabilidade monetária, converge, ao final, para a idéia de que o comércio exterior deve servir como "instrumento estratégico de desenvolvimento, sem ferir a estabilidade monetária".

Assim, a organização dos eventos comemorativos dos cinqüenta anos do IBRI, materializados nesse livro, presenteia o estudioso de Relaçóes Internacionais no Brasil com aquilo que tem sido, há meio século, a própria essência e razão de ser da instituição: promover e consolidar o pensamento brasileiro de forma aberta, múltipla e atual, mas, acima de tudo, brasileira. 